International

Medical Society

http://imedicalsociety.org

\title{
Elderly Assisted in the Family Health Strategy
}

Irapuan Medeiros de Lucena1, Matheus Figueiredo Nogueira², Sérgio Augusto Paredes Moreira3, Luípa Michele Silva ${ }^{4}$, Maria do Socorro Costa Feitosa Alves ${ }^{5}$, Antonia Oliveira Silva ${ }^{6}$, Ana Paula Abreu Borges ${ }^{7}$, José Luiz Telles de Almeida ${ }^{8}$, Clélia Albino Simpson ${ }^{9}$, Felismina Rosa Parreira Mendes ${ }^{10}$

\section{Abstract}

Introduction: The growth of the elderly population is a global phenomenon and, in Brazil, this transformation is happening in a very fast way.

Objective: Knowing the frequency of falls in the context of an aging population attended in a Health Family Unit

Method: This is a transversal research with a sample consisted of 121 elderly. A questionnaire was applied to the participants and the results were statistically analyzed with the Chi-Square test and Fisher's exact used to verify the association between variables.

Results: The results show that the majorities were female (76.9\%); concerning marital status, $35.3 \%$ are married; $92.1 \%$ with family income between one and two minimum wages; and $91.8 \%$ live with their spouse and/or children. The study showed a significant statistically association between female gender $(p=0.001)$, leading to the conclusion that there is a tendency that older woman suffers more falls than men. We found an occurrence of falls in $69.9 \%$ of women while this rate reaches $32.1 \%$ in male elderly.

Conclusion: Therefore, it is expected that these results can help to give a new look to the understanding of the falls with the Health Family Units.
1 Master, professor at the Federal Institute of Education, Science and Technology of Rio Grande do Norte, Parnamirim (RN), Brazil.

2 Doctoral Student, Federal University of Rio Grande do Norte, Natal (RN), Brazil.

3 Master's Student, Federal University of Paraíba, João Pessoa (PB), Brazil.

4 Doctoral Student, Federal University of Paraíba, João Pessoa (PB), Brazil Scholarship Holder of the Higher Education Personnel Improvement Coordination (CAPES), Brazil.

5 PhD, Chief Professor, Federal University of Rio Grande do Norte, Natal (RN), Brazil.

6 PhD, Chief Professor, Federal University of Paraíba, João Pessoa (PB), Brazil.

7 MMaster. Scholarship Holder of the National School of Public Health, Distrito Federal (DF), Brazil.

$8 \mathrm{PhD}$, director of the Oswaldo Cruz Foundation Regional Office for Africa based in Maputo-Mozambique, Oswaldo Cruz Foundation, Distrito Federal (DF), Brazil.

9 PhD, Professor, Federal University of Rio Grande do Norte, Natal (RN), Brazil.

10 PhD, Professor, University of Évora, Portugal.

\section{Contact information:}

Luipa Michele Silva.

Đluipams@gmail.com

\section{Keywords}

Elderly; Health; Falls; Family Health Strategy. 


\section{Introduction}

Aging is a natural and inevitable process for all. In Brazil, it has been happening at a very accelerated speed. Aging, today, is part of the reality of the majority of the world's societies and characterized differently across countries. In the most developed, aging occurred in a quite favorable economic and social scenario, differently than the developing countries, in which aging is in an accelerated growth in an inequity and social inequality panorama [1].

To Cancela [2] people do not age at the same way, in the aging process, the body ages as a whole, while its organs, tissues, cells and subcellular structures have different aging.

One of the aging characteristics is the progressive accumulation of disability, which comprises series of changes in organic and mental functions due exclusively to the effects of age on the organism, causing all physiological functions gradually start to decline [2].

One of the effects felt in the elderly body is decreased muscle strength, this reduction is related with sarcopenia, which is a physiological process of the human being which reduces involuntary the muscle mass and strength, making the elderly population more susceptible to falls $[3,4]$. Individual belonging to any age group is at risk of falling, but is in the elderly population that the risk of falls is more revealed [5].

The reduction of muscle mass and strength affects the elderly functionality, causing limitations as reduced mobility, reduced bone density and fractures by increasing the risk of falls [4-7].

Epidemiological studies show that $32 \%$ of the elderly population aged between 65 and 74 years old, 35\% between 75 and 84 years old and 51\% over 85 years old suffer fall at least once a year [8].

The falls generally may result in loss of autonomy and independence, in decision making, to do something through their own means, even for a limited time. Its most common consequences are fractures, immobility, activity restriction, the increased risk of institutionalization, health declining, psycho- logical damage as the fear of suffering further falls, rising costs of health care, social losses related to the family, making it difficult to interact with the community [9].

Pinho and Silva [10] observed in a study of the social representations of elderly on the risk of falls and aging, that were permeated by more negative dimensions as positive, noting the difficulties of elderly in this stage of life, and 63 elderly who fell, 71.4\% reported having experienced one to two falls.

Falls in the elderly are a concern, both for frequency as the consequences for quality of life. The falls are emerging, according to $\mathrm{WHO}$, as a major public health problem, because it has become evident due to the population explosion of elderly [11].

The objective of this study was to identify the frequency of falls of elderly assisted by Family Health Strategy of the Family Health Unit.

\section{Method}

This is a cross-sectional study. The study was conducted with the elderly accompanied by the Family Health Strategy. The places chosen for the questionnaire application were the Family Health Unit of Felipe Camarão, Natal - RN, linked to the Municipal Health Secretariat (SMS), and the elderly domiciles, located in the neighborhood where the FHU is located.

The unit was chosen because it is a partnership environment in the activities of the Federal University of Rio Grande do Norte - UFRN. For this study, the sample consisted of 121 elderly, which were chosen for convenience. The calculation of the sample size was performed by estimating exposure to fall $90 \%$ and considering a sampling error of $5 \%$ and $95 \%$ of confidence level.

The following criteria were considered for inclusion in the sample: be aged or over 60 years old; be resident in the area covered by the teams of the Family Health Strategy of the Felipe Camarão 
neighborhood; be registered and accompanied by health professionals of the Family Health Strategy of the BHU of Felipe Camarão, Natal - RN; accept freely to participate in the survey; sign the Informed Consent - IC; and present psychological conditions to answer to the data collection questionnaire. As exclusion criteria, it was considered not to be a resident of FHS coverage area of BHU Felipe Camarão and not have mental faculties compatible to the solvability of the questionnaire.

The study was approved by the Ethics Committee HUOL - Onofre Lopes University Hospital, of the Federal University of Rio Grande do Norte - UFRN, Opinion number 816,022, and followed the norms established in Resolution 466/2012 of the National Health Council/Ministry of Health that regulates the ethical principles of scientific research involving human subjects.

A questionnaire with closed questions about falls was used as a tool for data collection. This instrument was developed by the Postgraduate Program in Nursing, line of research Health Public Policies, of the Federal University of Paraíba - UFPB.

The distribution of the interviews was as follows: 61 elderly were interviewed at $\mathrm{BHU}$, at the time they sought care or information in the unit; and the other 60 participants were interviewed in their domiciles, or in the neighborhood Felipe Camarão.

For this analysis, the outcome used was the occurrence of falls in 2014, related to variables of personal information such as age, gender, living alone, practicing physical activity, among other variables. The distribution Tables were constructed across the outcome falls and the independent variables, which were tested by Chi-Square test and Fisher Exact, $p<0.30$. Data were typed, processed and statistically analyzed with SPSS software assistance - Statistical Package for the Social Sciences, version 22, with a confidence interval $(\mathrm{Cl})$ of $95 \%$. It was considered significant variables with association achieved less significance level of 0.05 .

\section{Results}

The study included 121 elderly registered and monitored in the Family Health Units of the Felipe Camarão neighborhood. The results were grouped in characterizing the personal, socioeconomic and demographic information and are presented in the following table 1, being the variables unveiled related to personal information such as age, gender, race, education, marital status and self-assessment of memory, data about family income, income source, and health care options.

In Table 1, there is a predominance of elderly aged from 60 to 79 years old, in a total of 107 (88.4\%) as the long-lived elderly, for this age group 14 participated (11.6\%) over the age of 80 years.

Table 1. Description of the sample of socioeconomic variables and related to personal information of the elderly accompanied by the Family Health Strategy of FHU of Felipe Camarão, Natal - RN ( $n=121)$.

\begin{tabular}{|c|c|c|c|}
\hline Variable & Categories & $\mathrm{n}$ & $\%$ \\
\hline \multirow{2}{*}{ Age } & Elderly & 107 & 88.4 \\
\hline & Long-lived & 14 & 11.6 \\
\hline \multirow{2}{*}{ Gender } & Male & 28 & 23.1 \\
\hline & Female & 93 & 76.9 \\
\hline \multirow{5}{*}{ Race } & White & 31 & 26.1 \\
\hline & Dark & 86 & 72.3 \\
\hline & Yellow & 1 & 0.8 \\
\hline & Black & 1 & 0.8 \\
\hline & Native & - & - \\
\hline \multirow{4}{*}{$\begin{array}{l}\text { Marital } \\
\text { status }\end{array}$} & Single & 20 & 16.8 \\
\hline & Married & 42 & 35.3 \\
\hline & Divorced/separated & 22 & 18.5 \\
\hline & Widower & 35 & 29.4 \\
\hline \multirow{6}{*}{$\begin{array}{l}\text { Self- } \\
\text { assessment } \\
\text { of memory }\end{array}$} & Excellent & 7 & 5.8 \\
\hline & Very good & 30 & 25.0 \\
\hline & Good & 48 & 40.0 \\
\hline & Regular & 28 & 23.3 \\
\hline & Bad & 6 & 5.0 \\
\hline & Very bad & 1 & 0.8 \\
\hline
\end{tabular}




\begin{tabular}{|c|c|c|c|}
\hline Variable & Categories & $n$ & $\%$ \\
\hline \multirow{5}{*}{$\begin{array}{l}\text { Family } \\
\text { income }\end{array}$} & $1 \mathrm{MW}$ & 58 & 50.9 \\
\hline & $2 \mathrm{MW}$ & 47 & 41.2 \\
\hline & 3 to $5 \mathrm{MW}$ & 9 & 7.9 \\
\hline & 6 to $9 \mathrm{MW}$ & - & - \\
\hline & $>10 \mathrm{MW}$ & - & - \\
\hline \multirow{6}{*}{$\begin{array}{l}\text { Personal } \\
\text { income } \\
\text { source }\end{array}$} & Retirement & 95 & 79.2 \\
\hline & Pension & 10 & 8.3 \\
\hline & Rent & - & - \\
\hline & Own work & 8 & 6.7 \\
\hline & Donations & 1 & 0.8 \\
\hline & Does not have & 6 & 5.0 \\
\hline \multirow{5}{*}{$\begin{array}{l}\text { First health } \\
\text { service } \\
\text { option }\end{array}$} & SUS & 91 & 94.8 \\
\hline & Health insurance & 3 & 3.1 \\
\hline & Particular & 2 & 2.1 \\
\hline & Pharmacy & - & - \\
\hline & Healer & - & - \\
\hline
\end{tabular}

As for participant's gender, most were female, in a total of 93 (76.9\%) compared to males, 28 (23.1\%). Regarding the race, it was verified the predominance of brown color, 86 (72.3\%), and white, $31(26.1 \%)$. Regarding marital status, the most significant results show that 42 (35.3\%) are married, 35 (29.4\%) widowed, divorced/separated, and singles are a total of $22(18.5 \%)$ and $20(16.8 \%)$, respectively.

As regards the self-assessment of memory, the more evident answers were good, 48 (40\%), very good, 30 (25\%), and regular, 28 (23.3\%), only one elderly reported that the memory was very bad; in this case it corresponded to $0.8 \%$ of the participants.

The last table data demonstrates the issues of income and access to health. Most elderly have income $(92.1 \%)$ and have a family income of up to two minimum wages, arising mainly from retirements and pensions, 79\% and $8.3 \%$, respectively.

According to Table 2, it proved data of the falls frequency in 2014 , with a percentage of $61.2 \%$ of
Table 2. Distribution of the sample for characteristics related to fall frequency in 2014 of the elderly accompanied by the Family Health Strategy of the FHU of Felipe Camarão, Natal. $R N(n=121)$.

\begin{tabular}{|c|c|c|c|}
\hline Variable & Categories & $\mathbf{n}$ & $\%$ \\
\hline \multirow{2}{*}{ Fall } & Yes & 74 & 61.2 \\
\hline & No & 47 & 38.8 \\
\hline \multirow{12}{*}{ Place } & Yard/backyard & 9 & 10.7 \\
\hline & Kitchen & 3 & 3.6 \\
\hline & Hall & - & - \\
\hline & Bedroom & 4 & 4.8 \\
\hline & Living-room & 12 & 14.3 \\
\hline & Bathroom & 5 & 6.0 \\
\hline & Service area & - & - \\
\hline & Sidewalk & 16 & 19.0 \\
\hline & Street/Avenue & 26 & 31.0 \\
\hline & Garden & 3 & 3.6 \\
\hline & $\begin{array}{l}\text { Climb in or down } \\
\text { vehicles }\end{array}$ & - & - \\
\hline & Other & 6 & 7.1 \\
\hline \multirow{2}{*}{$\begin{array}{l}\text { Made use of } \\
\text { alcohol }\end{array}$} & Yes & 2 & 2.5 \\
\hline & No & 77 & 97.5 \\
\hline \multirow{2}{*}{$\begin{array}{l}\text { Made use of } \\
\text { medication }\end{array}$} & Yes & 5 & 6.4 \\
\hline & No & 73 & 93.6 \\
\hline
\end{tabular}

Source: Authors, 2015.

Table 3. Distribution of the sample as the associated factors - intrinsic and extrinsic factors - falls in the elderly accompanied by Family Health Strategy of FHU of Felipe Camarão, Natal - RN ( $n=74)$.

\begin{tabular}{|l|l|c|c|}
\hline Variable & \multicolumn{1}{|c|}{ Categories } & n & $\%$ \\
\hline \multirow{2}{*}{ Fall cause } & Intrinsic factors & 4 & 4,8 \\
\hline & Extrinsic factors & 62 & 73,8 \\
\cline { 2 - 4 } & Both & 18 & 21,4 \\
\hline
\end{tabular}

Source: Authors, 2015. 
Table 4. Association between falls and the variables related to personal and lifestyle information of the elderly accompanied by Family Health Strategy of FHU of Felipe Camarão, Natal - RN ( $n=74)$.

\begin{tabular}{|c|c|c|c|c|c|c|}
\hline \multirow{2}{*}{ Variable } & \multirow{2}{*}{ Categories } & \multicolumn{2}{|c|}{ Fall } & \multirow{2}{*}{$\mathbf{R P}$} & \multirow{2}{*}{$\mathrm{Cl}(95 \%)$} & \multirow{2}{*}{$p$} \\
\hline & & Yes (\%) & No $(\%)$ & & & \\
\hline \multirow{2}{*}{ Age } & Elderly & $64(59.8)$ & $43(40.2)$ & 1.00 & \multirow{2}{*}{$0.49-5.70$} & \multirow{2}{*}{0.584} \\
\hline & Long-lived & $10(71.4)$ & $4(28.6)$ & 1.68 & & \\
\hline \multirow{2}{*}{ Gender } & Male & $9(32.1)$ & 19 (67.9) & 1.00 & \multirow{2}{*}{$1.98-12.16$} & \multirow{2}{*}{0.001} \\
\hline & Female & 65 (69.9) & $28(30.1)$ & 4.90 & & \\
\hline \multirow{2}{*}{ Living alone } & Yes & $7(70.0)$ & $3(30.0)$ & 1.53 & \multirow{2}{*}{$0.38-6.25$} & \multirow{2}{*}{0.739} \\
\hline & No & $67(60.4)$ & $44(39.6)$ & 1.00 & & \\
\hline \multirow{2}{*}{ Considers } & Independent & $55(58.5)$ & $39(41.5)$ & 1.00 & \multirow{2}{*}{$0.67-4.24$} & \multirow{2}{*}{0.373} \\
\hline & Partially dependent & $19(70.4)$ & $8(29.6)$ & 1.68 & & \\
\hline \multirow{2}{*}{$\begin{array}{l}\text { Practice physical } \\
\text { activity }\end{array}$} & Yes & $17(53.1)$ & $15(46.9)$ & 1.00 & \multirow{2}{*}{$0.28-1.44$} & \multirow{2}{*}{0.381} \\
\hline & No & $57(64.0)$ & $32(36.0)$ & 0.64 & & \\
\hline \multirow[b]{2}{*}{ Gait } & Normal & $60(60.0)$ & $40(40.0)$ & 1.00 & \multirow[b]{2}{*}{$0.50-3.60$} & \multirow[b]{2}{*}{0.746} \\
\hline & $\begin{array}{l}\text { Safe/unsafe with/without aid } \\
\text { equipment or unable }\end{array}$ & $14(66.7)$ & 7 (33.3) & 1.33 & & \\
\hline
\end{tabular}

elderly who fell one or more times in 2014 and $38.8 \%$ of the elderly who did not fall in that year. The places of greatest prevalence of falls were street/ avenue, with 31\%, sidewalk (19\%), living-room (14.3\%), yard/backyard (10.7\%), bathroom (6\%), bedroom $(4,8 \%)$, kitchen and garden with 3.6\% each, and other places have appeared in $7.1 \%$. Only $2.5 \%$ had used alcohol and $6.4 \%$ took medication before the fall.

The following table shows the falls suffered in 2014 and the most prevalent places.

The results of falls suffered by elderly accompanied by Family Health Strategy of FHU of Felipe Camarão, Natal - RN were found in Table 3. The data show that $73.8 \%$ of the elderly suffered the fall by extrinsic factors, $4.8 \%$ by intrinsic factors and $21.4 \%$ for both factors.

The table below shows the association between falls and the variables related to personal information such as age, gender, race, living alone, considered dependent or independent, practicing physical activity and gait. As shown in Table 4, we can see that there is a significant predominance of women in this age group.

\section{Discussion}

Currently, reaching old age is a population reality even in the poorest countries. Although the substantial improvement of the health parameters of populations observed in the twentieth century is far from being distributed equitably across different countries and socioeconomic contexts, aging is no longer the privilege of a few [1].

It should also be stressed that culturally women tend to use health services more frequently, which can be configured as a bias of sampling. And that this can be explained by the aging population trend, but also due to the female quota that is larger than the male [12].

State that the difference in marital status is a consequence of several factors, women have a longer 
expectation of life than men, tend to marry older men and to remain, widows, while men often remarry [13].

This logic, however, can explain the obtained result, which, associated with a higher male mortality than female, increases the woman's likelihood of survival in relation to their spouse [14].

The economic factor has a particularly significant effect on active aging, because the elderly that provides a better income, better retirement, are able to eat better, to buy the best-prescribed medicines, live well and use this income for a better quality of life, both socially and health. It is observed in many studies, that most of the elderly are a provider of their families [15].

Recent studies reveal that the low wages of the elderly limit access to goods and services consumption, for example, adequate food and housing, aggravating it when it turns out that the elderly are providers for their families. The search for the SUS was evident among those surveyed, totaling 94.8\% for the exclusive use of the Unified Health System, against $5.2 \%$ that uses both public and private systems, strengthening the issue of low-income presented by the elderly [16].

The etiology of falls is multifactorial, i.e., caused by many factors, thus, it is necessary to conduct a thorough evaluation to discover the causes of falls and related factors to minimize the risk and fall event. Such interventions should be multifactorial, emphasizing exercise for gait and balance training, changes in the used medications and in the physical environment, making it safer [17].

Among the main intrinsic factors, we can mention the physical changes associated with aging, decreased functional ability, an onset of chronic diseases, balance changes, osteoarticular diseases, inactivity, vision and hearing changes, and vertigo. Another major problem is associated with loss of muscle strength, as sarcopenia and muscle weakness are a universal feature of aging. The muscle weakness is referred as one of the most common causes of disability in the community, predisposing the elderly to falls and functional limitations [18].

Being elderly may allow the existence of a number of factors, which, in turn, may increase the risk of falls. Some associated factors contribute to the existence of falls, we can highlight that the fall event may be multifactorial and includes intrinsic and extrinsic conditions [18].

To Rocha [19], the intrinsic factors are those resulting from physiological changes associated with aging, from the own subject, as the functional capacity, advanced age, female, several chronic diseases, cognitive reduction, visual impairment, labyrinthitis, physical inactivity, depression, osteoporosis, sensory and motor disorders such as postural instability, decreased flexibility and mobility, muscle weakness, gait and balance changes, visual and hearing impairment, cognitive decline and medications use (polypharmacy). Also, diseases with disabling potential, such as stroke (cerebrovascular accident), are also more common in the elderly population and tend to aggravate the physiological problems that contribute to an increased risk of falls [20].

The extrinsic are more related to unsafe environmental risks, poorly designed and built, with architectural barriers, presence of stairs, lack of differentiation steps and handrails, poor lighting, loose rugs, slippery floors, obstacles such as electrical cords, clutter, poorly maintained floor in circulation location [21].

The occurrence of falls affects directly the quality of life for elderly. The majority of elderly who fall require medical attention, generating high costs to the public coffers. A major challenge for professionals who deal directly is to identify possible risk factors associated with this event and try to minimize these etiological factors [22].

In Brazil, in the period from 2001 to 2011 the growth in the number of elderly aged 60 years or more, in absolute terms, is striking: it went from 15.5 million people to 23.5 million. The majority of elderly populations are women (61.4\%) due to the 
effects of differential mortality by gender, which contributes to justify the results found in this study. It is evident, according to gender that women suffer a higher risk of falls than men. The table shows that factor, being statistically significant $(p=0.001)$ between males and females [20, 21].

When evaluating the inserted groups in health care programs, the presence of the majority of women is striking, as they seek more health services and specific groups. This observation lies in the fact that at least $30 \%$ of the elderly in Brazil suffer an episode of fall each year, women with a little higher falls frequency than men of the same age group [23].

Considering the influence of the presence or absence of a companion or family member to the occurrence of falls among the elderly, it is believed that the first is a protective factor and the second a risk factor, i.e., the company turns out to be a favorable aspect for the prevention of falls [24].

Elderly who live alone go out, probably, less frequently and therefore, are more prone to isolation, also have a social loss, depression, reduced fitness and increased mobility problems, causing physical, economic and emotional dependence, which may make the elderly more susceptible to falls. In this context, $91.8 \%$ of surveyed elderly live accompanied, as a proportion of $8.2 \%$ live alone.

Regarding the ADL (Activities of Daily Living), we found that $77.9 \%$ of the elderly are independent and $22.1 \%$ are partly dependent. To the extent that humans ages, many daily tasks, considered banal and, therefore, easy to perform, go slowly and often imperceptibly becoming increasingly difficult to be performed, until the individual realizes that now depends on someone else to take a simple bath, for example [14].

As for physical activity, we found only $27 \%$ who practice physical activity, while the sedentary are $73 \%$, a very high and alarming rate. The relation between physical activity, health, quality of life and aging is being increasingly discussed and scientificaIly analyzed, we know that the adoption of healthy lifestyles and active participation in their own healthcare are important at all stages of life $[5,6]$.

Engaging in appropriate physical activity, healthy diet, restriction of alcohol and tobacco, as well as the use of medicaments exclusively with medical advice, can prevent disease and functional decline, increasing longevity and the individual's quality of life [7].

It is possible that elderly gain independence to perform daily activities and to this independence they need to have good coordination, agility and dynamic balance, i.e., a good physical fitness, providing a suitable functional performance, thereby contributing to improving the quality of life of the individual $[25,26]$.

\section{Conclusions}

The falls etiology is multifactorial, i.e., caused by intrinsic factors cumulative interaction, which is directly related to aging and extrinsic factors, resulting in behavior and environment.

In this study, we observed a high frequency of falls in surveyed elderly. About $61.2 \%$ of study participants experienced, at least, one fall in 2014, which can be considered a worrying result, as this fall event in the elderly population is quite serious.

There was a statistically significant correlation with the female gender, leading to the conclusion that there is a trend that elderly women suffer more falls than men, we found an occurrence of falls in $69.9 \%$ of women while this index reaches $32.1 \%$ of male elderly.

Therefore, it is expected that these results can help to give a new look to the understanding of the falls with the Health Family Units. Therefore, the health team must constantly evaluate the occurrence of falls in the elderly to promote prevention strategies and thereby, provide them better-living conditions. It is important to highlight the need for further studies to identify the occurrence and associated factors of falls in the elderly. 


\section{References}

1. Veras R. Envelhecimento populacional contemporâneo: demandas, desafios e inovações. Rev. Saúde Pública, 2009; 43(3): 548-554. Available from: http://www.scielosp.org/pdf/ rsp/v43n3/224.pdf

2. Cancela DMG. O processo de envelhecimento. Trabalho de conclusão (estágio de complemento ao diploma de licenciatura em psicologia). Universidade Lusíada do Porto, Portugal. 2008; 15f. Available from: www.psicologia.com.pt.

3. Ochala J, et al. Single skeletal muscle fiber behavior after a quick stretch in young and older men: a possible explanation of the relative preservation of eccentric force in old age. Eur. J. Physiol., 2006; 452(4):464-470. doi: 10.1007/s00424-006-0065-6

4. Walrand $S$, et al. Physiopathological mechanism of sarcopenia. Clin. Geriatr. Med., 27(3): 365-385, 2011. doi: 10.1016/j. cger.2011.03.005.

5. Bandeira EMFS, Pimenta FAP, Souza MC. Atenção à saúde do idoso. Belo Horizonte. SAS/MG; 2006

6. Dellaroza MSG, Pimenta CAM, Lebrão ML, Duarte YAO, Braga PE. Associação entre dor crônica e autorrelato de quedas: estudo populacional ? SABE. Cad. Saúde Pública. 2014 mar; 30(3): 522-532. http://dx.doi.org/10.1590/0102-311X00165412.

7. Nóbrega $A C L$, et al. Posicionamento oficial da Sociedade Brasileira de Medicina do Esporte e da Sociedade Brasileira de Geriatria e Gerontologia: atividade física e saúde no idoso. Rev Bras Med Esporte. 1999 dec; 5(6): 207-211. http://dx.doi. org/10.1590/S1517-86921999000600002.

8. Baraff, LJ et al. Practice guideline for the ED Management of falls in community - dwelling elderly persons. Ann. Emerg. Med. 1997; 30(4):480-9. doi:10.1016/S0196-0644(97)70008-8

9. Perracini MR, Ramos LR. Fatores associados a quedas em uma coorte de idosos residentes na comunidade. Rev. Saúde Pública. 2002; 36(6):709-716. http://dx.doi.org/10.1590/S003489102002000700008

10. Pinho TAM, Silva AO. Avaliação do risco de quedas em idosos na perspectiva das representações sociais. Dissertação (Mestrado). Centro de Ciências da Saúde, Universidade Federal da Paraíba. João Pessoa. 2009; 82f.

11. Rodrigues J, Ciosak SI. Idosos vítimas de trauma: uma proposta de predição de riscos. Rev. Esc. Enferm. USP. 2012; 46(6): 1400-1405.

12. Instituto Brasileiro de Geografia e Estatística. Censo Demográfico 2010. Rio de Janeiro, IBGE, 2014. Disponível em <http:// censo2010.ibge.gov.br>

13. Smeltzer CS, et al. Tratado de enfermagem médico-cirúrgica. 11a edição. Rio de Janeiro. Guanabara Koogan; 2010.

14. Motta LB, Aguiar AC. Prevalência e fatores associados a quedas em idosos em um município do Rio de Janeiro. Rev. Bras. Geriátrica. 2010; 13(1): 83-91. http://dx.doi.org/10.1590/S180998232010000100009

15. Veras RP. Um modelo em que todos ganham: mudar e inovar, desafios para o enfrentamento das doenças crônicas entre os idosos-. Acta Scientiarum. Human and Social Sciences. 2012; 34(1): 3-8. doi: 10.4025/actascihumansoc. v34i1. 16181.

16. Duarte $L R$, et al. Hábitos de consumo de medicamentos entre idosos usuários do SUS e de plano de saúde. Cad Saúde Colet. 2012; 20(1): 64-71. Available from: http://iesc.ufri.br/cadernos/ images/csc/2012 1/artigos/CSC v20n1 64-71.pdf.
17. Machado TR, Oliveira CJ, Costa FBC, Araujo TL. Avaliação da presença de risco para queda em idosos. Rev. Eletr. Enf. [Internet]. 2009; 11(1):32-8. Available from: http://www.fen.ufg. br/revista/v11/n1/v11n1a04.htm

18. Rezende, Luis Guilherme Rosifini Alves, and Mario Jefferson Quirino Louzada. Quedas no paciente idoso: o papel do ortopedista na prevenção. Archives of Health Investigation. 2015; 4(2):25-34. Available from: http://www.archhealthinvestigation. com.br/index.php/ArcHI/article/view/892/1175.

19. ROCHA, A. C. A. L. A espiritualidade no manejo da doença crônica do idoso. Dissertação (mestrado em Enfermagem), Universidade de São Paulo. São Paulo. 2011; 86 f.

20. Brasil. Portaria $n^{\circ} 648 / G M$, de 28 de março de 2006. Aprova Política Nacional de Atenção Básica, estabelece a revisão de diretrizes e normas para a organização da Atenção Básica para o Programa Saúde da Família (PSF) e o Programa Agentes Comunitários Saúde (PACS). Brasília: 2006. Available from: $\underline{\text { http:// }}$ bvsms.saude.gov.br/bvs/publicacoes/prtGM648 20060328. pdf.

21. Machado FN, Machado NA, Soares SM. Comparação entre a capacidade e desempenho: um estudo sobre a funcionalidade de idosos dependentes. Rev. Latino-Am. Enf. 2013; 21(6): 13219. doi: 10.1590/0104-1169.2682.2370

22. Philbois SV, Martins J, Souza CS, Sampaio RF, Oliveira AS. Health professionals identify components of the International Classification of Functioning, Disability and Health (ICF) in questionnaires for the upper limb. Braz. J. Phys. Ther. 2016; 20(1): 15-25. http://dx.doi.org/10.1590/bjpt-rbf.2014.0135.

23. Siqueira $F V$, et al. Prevalência de quedas em idosos e fatores associados. Rev Saúde Pública. 2007; 41(5):749-56,. http://dx.doi.org/10.1590/S0034-89102007000500009

24. Soares DS, Mello LM, Silva AS, Nunes AA. Análise dos fatores associados a quedas com fratura de fêmur em idosos: um estudo caso-controle. Rev. bras. geriatr. gerontol. 2015 jun; 18(2):23948. http://dx.doi.org/10.1590/1809-9823.2015.14022.

25. Hyatt $\mathrm{RH}$, et al. Association of muscle strength with functional status of elderly people. Age and Ageing. 1990; 19(5):330-6. doi: 10.1093/ageing/19.5.330

26. Rosa TEC, Benicio MHD, Latorre MRDO, Ramos LR. Fatores determinantes da capacidade funcional entre idosos. Rev. Saúde Pública USP. 2003; 37(1):40-8. http://dx.doi.org/10.1590/ $\underline{\mathrm{S} 0034-89102003000100008}$

\section{Publish in International Archives of Medicine}

International Archives of Medicine is an open access journal publishing articles encompassing all aspects of medical science and clinical practice. IAM is considered a megajournal with independent sections on all areas of medicine. IAM is a really international journal with authors and board members from all around the world. The journal is widely indexed and classified Q1 in category Medicine. 